Piwulang 8(1)(2020)
Teaching
http://journal.unnes.ac.id/sju/index.php/piwulang

\title{
PENGEMBANGAN PENILAIAN AUTENTIK PEMBELAJARAN TEKS DIALOG BAHASA JAWA KELAS VII
}

\author{
Siti Meliana ${ }^{1}$, Esti Sudi Utami ${ }^{2}$, Joko Sukoyo ${ }^{3}$ \\ 1,2,3Jurusan Bahasa Jawa, Fakultas Bahasa dan Seni, Universitas Negeri Semarang, Indonesia \\ Corresponding Author: sitimeliana35@gmail.com ${ }^{1}$
}

\begin{abstract}
Abstrak
Penilaian merupakan satuan proses pembelajaran yang dilakukan untuk mengukur kemampuan siswa pada kompetensi dasar tertentu. Kurangnya referensi guru tentang penilaian teks dialog menjadi kendala dalam memberikan penilaian kepada siswa. Keterbatasan tersebut dijadikan dasar perlunya pengembangan instrumen penilaian yang dapat membantu guru dalam melakukan penilaian. Penelitian ini bertujuan untuk mengembangkan instrumen penilaian pembelajaran teks dialog bahasa Jawa. Penelitian ini menggunakan metode penelitian dan pengembangan, dengan lima tahapan penelitian, meliputi identifikasi potensi dan masalah, pengumpulan data, desain produk, validasi desain, serta revisi desain. Pengumpulan data menggunakan teknik wawancara dan angket. Hasil penelitian ini berupa instrumen penilaian autentik pembelajaran teks dialog bahasa Jawa. Instrumen penilaian tersebut berupa soal pilihan ganda, penugasan, unjuk kerja/praktik, dan produk. Hasil validasi menunjukkan perolehan skor rata-rata pada soal pilihan ganda 11,72 (cukup) dari ahli evaluasi dan skor 12,11 (baik) dari ahli guru, sedangkan skor rata-rata penilaian penugasan, unjuk kerja/praktik, dan produk 3,7 (baik) dari ahli dan 3,1 (cukup) dari guru. Perbaikan dilakukan pada pemilihan diksi, struktur kalimat, dan perbaikan pilihan jawaban.

Kata Kunci: penilaian; autentik; teks dialog
\end{abstract}

\begin{abstract}
Assessment is once of process study which is conducted to measure of students by basic competency. Lack of reference of teachers for assessment dialog text make an obstacles for giving assessment to students. This limitation made basic must be need assessment of development technique where can helping teachers to be give an assessment. This research have a purpose to development learning instrument assessment dialog of text Javanesse Language. This research have use research and development method, with five stage of research, include identivity potencyl and problem, data collection, design product, validation design and then revition of design. Collection data used by interviews and questionnaires instrument. Result of this research in the form of autenthic assessment learning dialog text Javanesse Language. The assissment of instrument is question of multiple choice, task, work method/practice and product. Result of validation has showing aquisition average score at question of multiple choice 11,72 (enough) from evaluation expert and score 12,11 (good) from teacher expert, and while the average score assessment of tasking, work method/practice, and product 3,7 (good) from expert and 3,1 (enough) from teachers. Repaired has doing on selection of diction, sentence structure, and repair choice answers.
\end{abstract}

Keywords: authentic; assessment; dialog text

(C) 2020 Universitas Negeri Semarang

p-ISSN 2252-6307

e-ISSN 2714-867X 
Siti Meliana, dkk/ Piwulang 8 (1) (2020)

\section{PENDAHULUAN}

Penilaian dilakukan pada akhir pembelajaran baik secara individu ataupun berkelompok. Penilaian bertujuan untuk mengetahui pemahaman materi setiap siswa secara individu. Penilaian disusun dan dilaksanakan sesuai kurikulum yang berlaku di sekolah. Penilaian autentik adalah kegiatan menilai siswa yang menekankan pada apa yang seharusnya dinilai, dengan berbagai instrumen penilaian sesuai kompetensi dasar tertentu (Kunandar 2013: 35-36).

Penerapan penilaian autentik diharapkan dapat mengukur kemampuan siswa pada kompetensi dasar tertentu. Penilaian autentik terdiri dari penilaian kompetensi pengetahuan dan penilaian kompetensi keterampilan. Penilaian dapat dilakukan secara tes maupun non tes, sesuai dengan kompetensi dasar yang akan dinilai.

Sasaran penilaian pembelajaran teks dialog bahasa Jawa adalah mengetahui kemampuan membaca, berbicara dan menulis teks dialog sederhana. Dialog bahasa Jawa mempunyai ciri khas tersendiri dibandingkan dengan bahasa- bahasa lain. Kosakata dalam percakapan bahasa Jawa terdapat tingkat kesopanan berbeda ketika digunakan untuk diri sendiri dan orang yang lebih tua. Suatu untaian kalimat disebut ngoko atau krama sebenarnya bergantung pemakaian dan pemilihan leksikon atau kata (kosakata) di dalam kalimat itu secara tepat (Sasangka 2004: 24).

Sebuah percakapan dilaksanakan minimal oleh dua orang dengan kosakata atau kalimat yang tidak menyinggung perasaan orang lain. Interaksi verbal yang berlangsung secara tertib dan teratur dengan melibatkan dua pihak atau lebih guna mencapai tujuan tertentu sebagai wujud peristiwa komunikasi (Rustono 1999: 50).

Guru sudah berupaya untuk memberikan penilaian yang sesuai dengan kompetensi dan kondisi siswa di sekolah. Salah satu permasalahan yang dihadapi oleh guru dalam melakukan penilaian yaitu referensi penilaian yang terbatas.

Pentingnya penilaian untuk mengetahui kemampuan membaca, berbicara, dan menulis dialog sederhana secara asli atau falid mendorong perlunya pemecahan permasalahan di atas. Oleh karena itu, penelitian ini bertujuan untuk mengembangkan teknik atau instrumen penilaian autentik untuk pembelajaran teks dialog bahasa Jawa bagi siswa kelas VII. Hasil penelitian ini diharapkan dapat menjadi referensi bagi guru dalam pelaksanaan penilaian pembelajaran teks dialog serta dapat memudahkan siswa dalam mengikuti penilaian.

\section{METODE PENELITIAN}

Penelitian ini dirancang dengan metode Research and Development. Tahapan penelitian ini meliputi (1) analisis potensi dan masalah, (2) pengumpulan data, (3) desain produk, (4) validasi desain, dan (5) revisi desain.

Data penelitian ini mencakup data kebutuhan siswa, data kebutuhan guru, data penilaian ahli evaluasi, dan guru sebagai calon pengguna. Sumber data penelitian ini meliputi 30 siswa SMP Negeri 2 Ungaran, 1 guru bahasa Jawa 
Siti Meliana, dkk/ Piwulang 8 (1) (2020)

SMP Negeri 1 Ungaran, 2 guru SMP Negeri 2 Ungaran, 2 guru SMP An-Nur Ungaran, dan dosen ahli evaluasi bahasa Jawa. Data dikumpulkan dengan teknik wawancara dan angket. Instrumen yang digunakan dalam penelitian meliputi pedoman wawancara guru, angket kebutuhan siswa, angket kebutuhan guru, dan angket penilaian prototipe. Analisis data penelitian menggunakan teknik analisis deskriptif kualitatif.

\section{HASIL DAN PEMBAHASAN}

Hasil pengumpulan data kebutuhan siswa dan guru terhadap instrumen penilaian autentik pembelajaran teks dialog bahasa Jawa dijelaskan dalam uraian berikut. Siswa dan guru membutuhkan penilaian autentik pembelajaran teks dialog bahasa Jawa. Hal ini terlihat dari 30 responden, diperoleh $90 \%$ siswa setuju jika dilakukan pengembangan penilaian. Dari lima guru responden, semuanya mendukung pengembangan penilaian autentik pembelajaran teks dialog bahasa Jawa kelas VII.

Siswa menginginkan pengembangan penilaian autentik menggunakan bahasa yang mudah untuk dipahami dan disertai gambar menarik. Guru menginginkan penilaian autentik yang memunculkan tokoh tua dan muda, permasalahan yang biasa dialami siswa pada kehidupan sehari-hari, dan unsur unggahungguh. Guru setuju jika produk yang dihasilkan dicantumkan ilustrasi dan gambar yang jelas.

Pengembangan produk dilakukan berdasarkan data kebutuhan di atas. Hasil akhir pengembangan berupa prototipe instrumen untuk mengukur aspek pengetahuan dan keterampilan siswa. Penilaian aspek pengetahuan berupa instrumen pilihan ganda dan penugasan, serta penilaian aspek keterampilan berupa instrumen unjuk kerja/praktik dan produk.

Prototipe desain produk berupa buku kerja siswa yang terdiri dari 15 soal pilihan ganda. Instrumen penilaian pilihan ganda yang dikembangkan menuntut siswa untuk (1) menentukan diksi yang tepat, (2) menentukan penulisan kata sapaan yang benar, (3) menentukan isi teks dialog yang tepat, dan (4) menentukan teks dialog sesuai dengan penulisan ejaan yang tepat. Soal pilihan ganda berupa pertanyaan dan pilihan jawaban berbentuk pernyataan atau kalimat yang terdiri dari jawaban benar dan salah sebagai pengecoh. Hal ini juga disampaikan Hosnan (138: 2014), soal tes berbentuk pilihan ganda terdiri atas pembawa pokok persoalan yang dapat dikemukakan dalam bentuk pertanyaan maupun pernyataan yang belum sempurna dan pilihan jawaban.

Berbeda dengan instrumen pilihan ganda, instrumen penugasan berupa tugas menulis siswa secara kelompok. Instrumen penugasan diharapkan dapat membantu siswa dalam menyusun teks dialog sesuai tema yang telah ditentukan berdasarkan unggah-ungguh basa yang tepat.

Instrumen unjuk kerja/praktik berisi konteks dan penggalan teks dialog sebagai acuan dalam mengukur kemampuan berbicara siswa. Siswa diminta menyusun teks dialog berdasarkan konteks dan melengkapi teks dialog secara lisan yang kemudian dipraktikkan bersama kelompoknya. Hal ini sesuai dengan pernyataan 
Siti Meliana, dkk/ Piwulang 8 (1) (2020)

Hosnan (401: 2014) yang menyatakan bahwa penilaian kinerja merupakan penilaian yang menuntut peserta didik melakukan tugas dalam bentuk perbuatan yang dapat diamati oleh pendidik.

Instrumen penilaian yang terakhir adalah produk yang berisi tugas menulis teks dialog sederhana secara individu. Praktek menulis yang dilakukan oleh siswa terdiri tiga tahapan yaitu tahap persiapan, proses pembuatan produk, dan penilaian produk. Penilaian produk ini sesuai dengan pendapat Hosnan (406: 2014) yang menyatakan bahwa penilaian produk adalah penilaian terhadap proses pembuatan dan kualitas suatu produk.

Masing-masing soal pilihan ganda disertai penggalan dialog sebagai acuan dalam menjawab pertanyaan. Setiap penggalan teks dialog terdiri dari 2-3 tokoh tua dan muda. Hal ini bertujuan agar siswa dapat menerapkan secara nyata pada kehidupan sehari-hari. Tema pada instrumen penugasan disertai gambar dan ilustrasi yang sesuai. Konteks pada instrumen unjuk kerja/praktik berisi ilustrasi yang jelas dengan menyertakan tokoh tua dan muda. Berbeda halnya dengan instrumen produk yang membebaskan siswa dalam menentukan tema untuk membuat teks dialog. Namun, siswa diwajibkan menyertakan kata-kata yang tersedia menjadi kalimat bagian teks dialog yang disusun.

Uji validasi melibatkan dua orang yaitu ahli evaluasi dan guru sebagai calon pengguna. Hasil uji validasi ahli menunjukkan dari skor maksimal 15 untuk soal pilihan ganda, skor ratarata penilaian ahli evaluasi adalah 11,72 yang berarti cukup. Perbaikan pada soal pilihan ganda meliputi perbaikan diksi, petunjuk pengerjaan soal, pilihan jawaban yang kurang homogen, dan pilihan jawaban yang lebih dari satu. Skor ratarata yang didapat dari penilaian penugasan, unjuk kerja, dan produk adalah 3,7 yang berarti baik.

Perbaikan pada penilaian penugasan, unjuk kerja/praktik, dan produk meliputi perbaikan petunjuk pengerjaan soal dan struktur kalimat. Adapun skor rata-rata soal pilihan ganda yang didapat dari penilaian guru sebagai pengguna adalah 12,11 yang berarti cukup baik. Skor rata- rata untuk penilaian penugasan, unjuk kerja, dan produk adalah 3,1 yang berarti cukup. Saran guru untuk perbaikan yaitu unggahungguh basa yang digunakan harus lebih diperhatikan.

\section{SIMPULAN}

Berdasarkan uraian di atas, dapat disimpulkan produk ini layak digunakan sebagai alternatif penilaian autentik dalam pembelajaran teks dialog bahasa Jawa siswa kelas VII.

\section{DAFTAR PUSTAKA}

Hosnan. M. 2014. Pendekatan Saintifik dan Kontekstual dalam Pembelajaran Abad 21. Kunci Sukses Implementasi Kurikulum 2013. Bogor: Ghalia Indonesia.

Kunandar. 2013. Penilaian Autentik (Penilaian Hasil Belajar Peserta Didik Berdasarkan Kurikulum 2013). Suatu Pendekatan Praktis. Jakarta: Rajagrafindo Persada.

Rustono. 1999. Pokok-Pokok Pragmatik. Semarang: IKIP Semarang Press. 
Siti Meliana, dkk/ Piwulang 8 (1) (2020)

Sasangka, Sry Satria Tjatur Wisnu. 2004.

Unggah-ungguh Bahasa Jawa. Jakarta:

Yayasan Paramalingua. 